DOI:

УДК 669.136 .9

О.Г. Чернета, к.т.н., доцент

В.І. Сухомлін, к.т.н., доцент

С.В. Калініченко, аспірант

Дніпровський державний технічний університет, м. Кам'янське

\title{
ДОСЛІДЖЕННЯ ВІДНОВЛЕНОГО ПОВЕРХНЕВОГО ШАРУ ДЕТАЛЕЙ ІЗ СТАЛІ 45 ІЗ ЗМІЦНЮЮЧОЮ ОБРОБКОЮ НА ЗНОСОСТІЙКІСТЬ
}

В роботі розглянуті сучасні методи змічнення відтворених робочих поверхней деталей, підібрані технологічні режсим наплавки, обробки і зміцнення поверхневих шарів. Проведені дослідження мікроструктури, рентгенофазового аналізу, трибологічні іспити зміцнених шарів сталі 45 з наплавленим шаром електродів ОЗШ -3 деталей автомобілів. розглянуті питання формоутворення пошарових зон в поверхневих шарах відновлювальної деталі, особливості структурної будови і властивості робочої поверхні після лазерної обробки з боровмімуючої обмазкою. Проведений иикл вимірювань мікротвердості робочих шарів змічненого шару.

Ключеві слова: відтворення; зміинення; мікроаналіз; зносостійкість; мікроструктура; рентгенофазовий аналіз.

Modern methods of strengthening the reproduced working surfaces of parts are considered in the work, technological regimes of surfacing, processing and strengthening of surface layers are selected. Microstructures, X-ray diffraction analysis, tribological examinations and hardened layers of steel 45 with a layer of electrodes OZS-3 of car parts have been carried out. the questions of formation of layered zones in the surface layers of the restorative part, features of structural structure and properties of the working surface after laser treatment with a batting pad are considered. Conducted a cycle of measurements of microhardness of the working layers of the strengthened layer.

Keywords: reproduction; strengthening; microanalysis; wear resistance; microstructure; $X$-ray diffraction analysis.

\section{Постановка проблеми}

Від зносостійкості робочої поверхні деталей машин в більшому разі залежить і ефективність концевого результату — надійність, довговічність і стабільність роботи агрегатів, вузлів і в цілому автомобіля. Рішення проблем зносостійкості контактуючих пар тертя є безперечно важливим фактором для забезпечення високого ресурсу роботи виробів, а вимоги і умови підвищення зносостійкості спонукають застосовувати новітні технології і технологічні методи.

\section{Аналіз останніх досліджень і публікацій}

Відомо багато методів зміцнення поверхневих шарів $[1,2]$, але у сучасному виробництві впроваджуються новітні технології з використанням високоенергетичих засобів, приладів, що дає змогу підвисити ефективність, продуктивність і собівартість технологічних процесів, забезпечити заданими характеристиками міцності, твердості, зносостійкості оброблюємі поверхні локальних робочих зон контактуючих пар деталей $[3,4]$. Використання комбінованих технологій дозволяє послідовно формувати пошаровий склад структур у матеріалі з заданими властивостями з використанням легованих елементів і фаз впровадження. Перевагами новітніх комбінованих технологій безперечно $\epsilon$ те, що робоча поверхня деталі підлягає попередньому насиченню елементами $(\mathrm{O}, \mathrm{C}, \mathrm{B}, \mathrm{N})$ з подальшою лазерною обробкою, обробкою ТВЧ, що утворюють надтверді зміцнюючи структури (оксиди, карбіди, бориди, нитріди, або складні їх комбінації - карбобориди, карбонітриди, оксикарбонітриди) $[5,6]$.

\section{Формування мети дослідження}

Мета роботи - встановити закономірності механізму формування зносостійких, надтвердих мікроструктур в поверхневому шарі за рахунок використання комбінованих технологій борування і лазерної обробки. 


\section{Виклад основного матеріалу}

Як доведено всебічними дослідженнями, лазерна обробка сприяє подрібленню зерен основної структури матеріалу [6,7]. В поверхневому шарі в результаті перезагартування утворених структур виникають нові структури і фази. Карбіди, нітриди, бориди, оксиди в деяких випадках в результаті лазерної обробки, що характеризується над швидкими процесами нагріву і охолодження, створюють нові структури і складні формоутворення, такі як карбонітриди, оксикарбонітриди, борокарбіди, що є невідмінною складовою при наявності в різних сталях легованих елементів і які також самостійно вступають в процеси утворення структур і фаз. Часом виявити і індифікувати нові структури і фази - доволі складна задача, що потребує всебічну інформаційну базу, спеціальне обладнання і пристрої для підготовки, дослідження і вивчення специфічних утворень.

Для відновлення робочої поверхні кулачків із сталі 45 використовували електроди ОЗШ-3 з наступним хімічним складом $(\mathrm{C}-0,4 \% ; \mathrm{Mn}-0,5 \%$; $\mathrm{Si}-1,9 \%$; $\mathrm{Cr}-9,9 \%$; $\mathrm{S}-0,013 \% ; \mathrm{P}-0,021 \%)[6,7]$. Технологія відновлення здійснювалась наступним чином. Спрацьовані поверхні механічно оброблювалися різальним інструментом. Знімався шар до 2 мм поверхні з наступним відновленням за допомогою зварювальних електродів ОЗШ-3. Для формування потрібної геометрії форми кулачка і зняття шару нерівності поверхні, що утворилася в наслідок зварювального наплавлення, використовували лезвійну обробку з фінішним шліфуванням робочої поверхні. Для зміцнення поверхневого шару деталі застосовували імпульсний лазер ГООС-1 3 енергією накопичення 40 Кдж, відстанню до мішені 290 мм, діаметром лазерної плями 9 мм. Попередньо зону лазерної обробки покривали боровміщуючою обмазкою (клейова суміш порошкового бору фракції 0,3-0,5 i «Supermonolit» (TU U-2406-30440956-00302). Товщина боровміщуючої обмазки на поверхні кулачка складала $1,1-1,5$ мм. Лазерну обробку проводили з перекриттям відповідних зон обробки за рахунок переміщення лазерного променя по поверхні, переміщуючи і обертаючи тіло кулачка навколо вісі обертання. Колоподібна пляма лазерного випромінювання діаметром 9 мм при послідовній лазерній обробці перекриває по площі всі відповідні зони обробки. Для кулачка розподільного валу двигуна внутрішнього згорання легкового автомобіля знадобилося до 10 лазерних імпульсів. Інтервал обробки за допомогою лазерних імпульсів складав до 5 хвилин для накопичення відповідної енергії. Залишки продуктів лазерного випромінювання на поверхні усували механічним способом і розчинів. Поверхню обробки шліфували за допомогою шліфувального папіру № 1 , № 0 і полірували за допомогою паст з вмістом карбіду тітану КТ 3/2 НОМГ (ТУ У 22545935,001-2000).

На рис. 1 а (609), б (613) надана фотографія, що одержана за допомогою електронного мікроскопу PЕМ-2, бічної поверхні наплавленого кулачка де чітко виражені основні шари і зони лазерного впливу. Наплавлений поверхневий шар товщиною до 40 мкм має мілко подріблену структуру і більш темне забарвлення. Чітко виражена і гранична зона переходу від наплавленої зони до основного металу з феріто-перлітною структурою. На фотографіях рис. 1 в $(601 \times 5,00 \kappa)$, г $(602 \times 2,500 \kappa)$, д $(603 \times 1,00 \kappa)$ при різних збільшеннях сталі 45 з наплавленим шаром спостерігається скопичення витягнутих голкоподібних рійок, що характерні зонам відпуску і відповідають структурам верхнього бейніту.

Рейкоподібні структурні утворення $\epsilon$ наслідком температурних коливань при охолодженні на повітрі і класифікуються як верхній бейніт. Ферито-цементитна структура у шарі спостерігається по границях зерен у вигляді пластин фериту. Розміри зерен і рійок коливаються від 10-20 мкм.

На рис. 1 е $(605 \times 2,500 \kappa)$, ж $(607 \times 1,00 \kappa)$, з $(606 \times 1,00 \kappa)$ спостерігається феріто-карбідна структура основного металу сталі 45 - колонії зерен темного і світлого забарвлення з розмірами відповідно 8-15 мкм і 5-10 мкм. Фотографії зразків $(606 \times 2,500 \kappa)$, ж $(607 \times 1,00 \kappa)$, рис. 1 з, ж і рис. 2 а виявляють в глибинному шарі скупчення зерен пластинчатого перліту і цементиту. Під поверхневий шар (25 мкм від поверхні) рис. 2 а $(608 \times 500) \sigma(610 \times 5,00 \kappa)$, в, г $(612 \times 5,00 \kappa)$ має окремі білі вкраплення бору, що $є$ результатом лазерного борування. Розміри цих окремих часток не перевищує 5 мкм. 

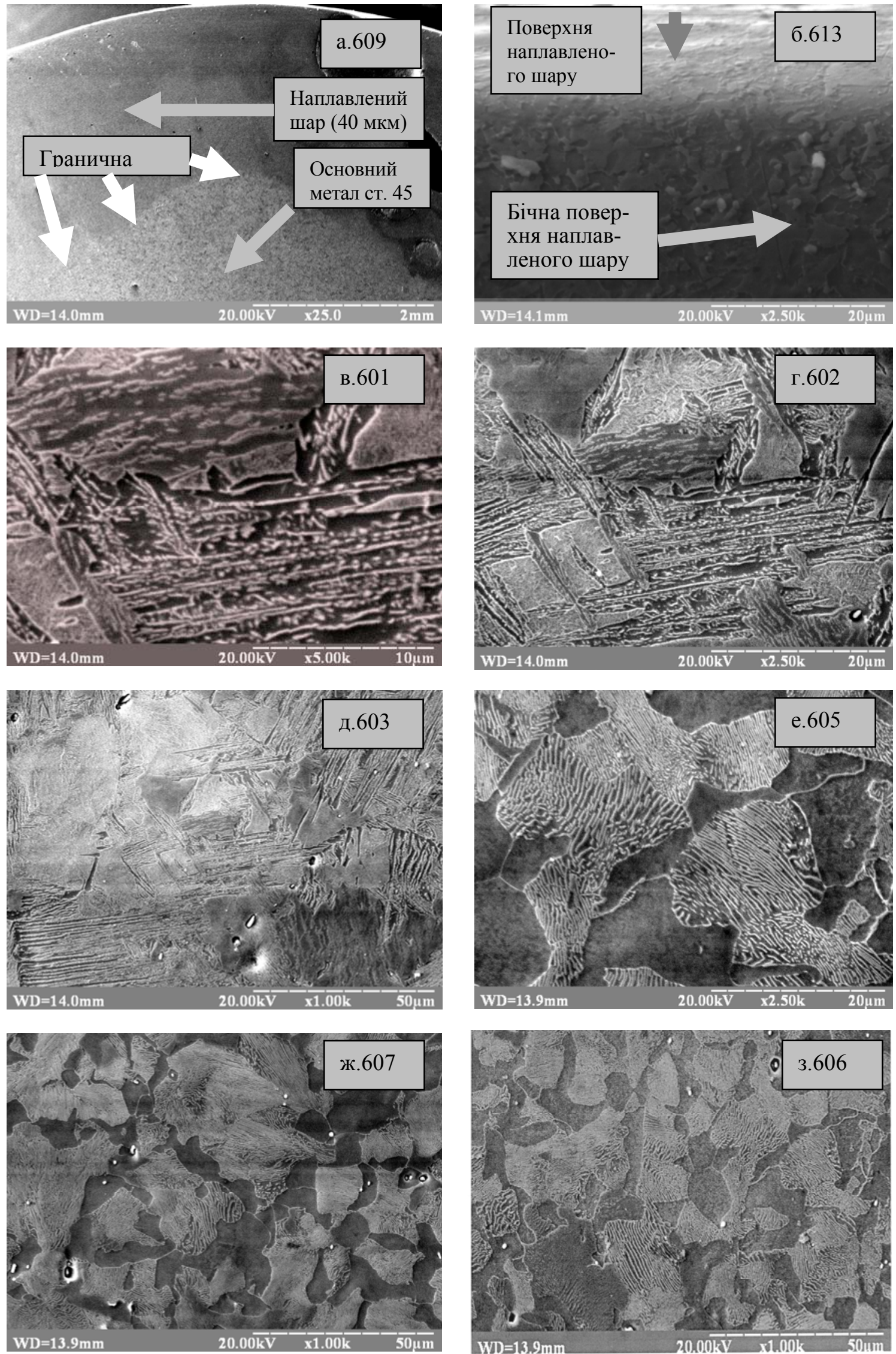

Рuc. 1. (а-з) Мікроструктури відповідних зон зразка із сталі 45 з наплавленим шаром О3Ш-3 

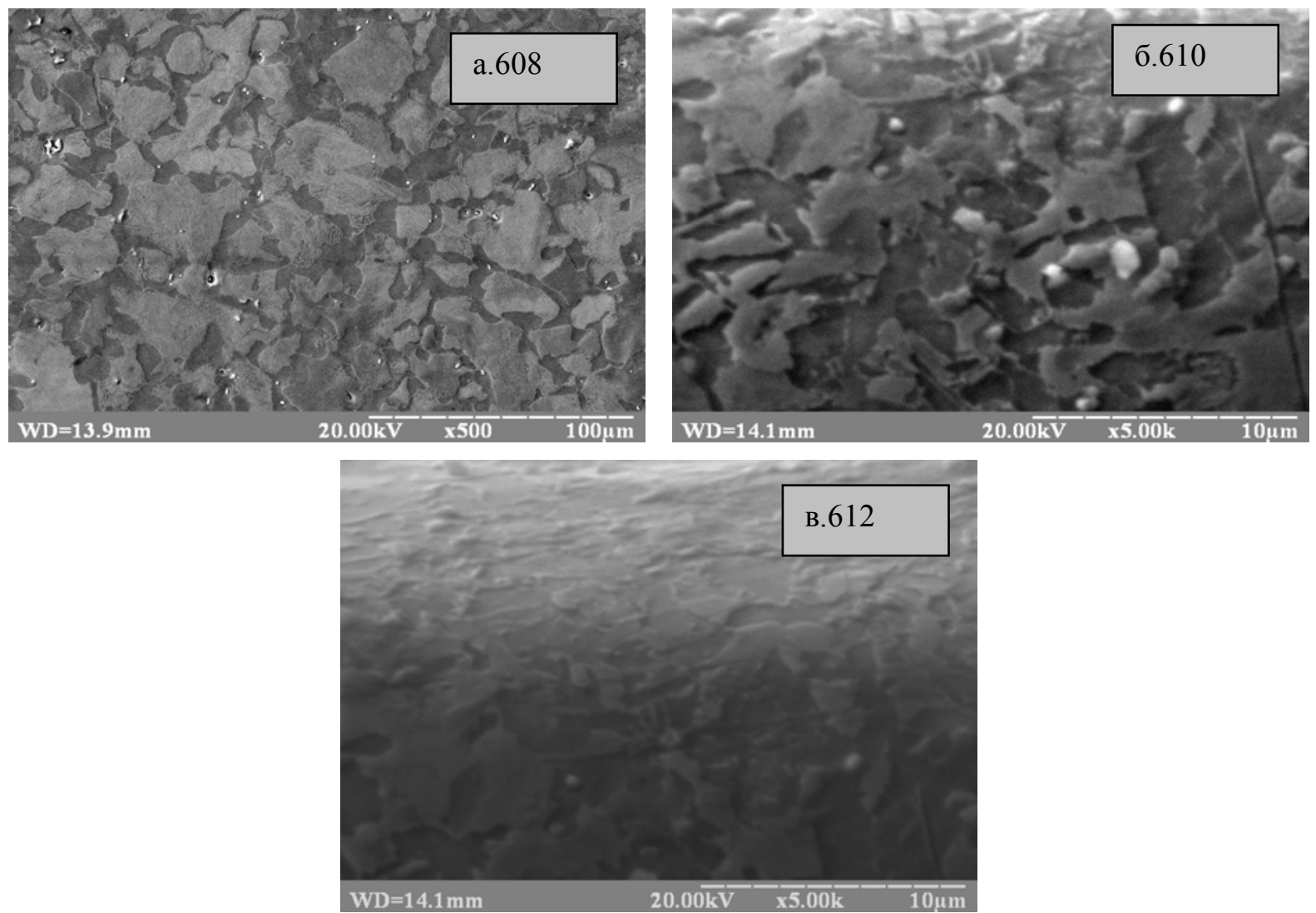

Рuc. 2. (а-в) Мікроструктури відповідних зон зразка із сталі 45 з наплавленим шаром О3Ш-3

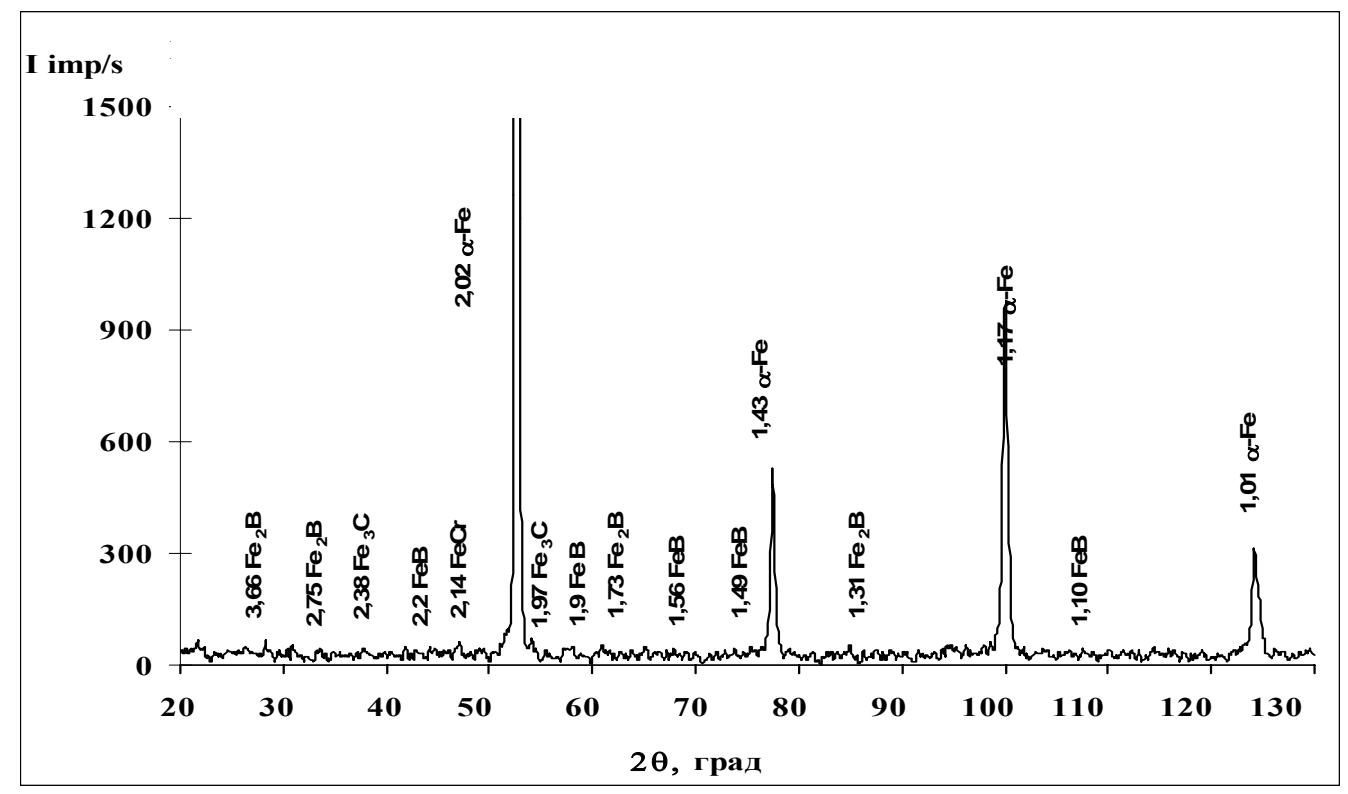

Рис. 3. Рентгенівська дифрактограма кулачка 3 сталі 45 з наплавленим шаром електродами ОЗШ-3 Со-Ка випромінювання 
Рентгенофазовий аналіз проводили на рентгеновскому дифрактометрі ДРОН-2 в монохроматизованному Со-Ка випромінюванні $(\lambda=1.7902$ А). Ідентифікацію фаз проводили шляхом порівняння міжплощинних відстаней $(d, \mathrm{~A})$ і відносних інтенсивностей (I otn- $\left.\mathrm{I} / \mathrm{I}_{0}\right)$ експериментальної кривої з данними електронної картотеки PCPDFWIN $[8,9,10]$.

Як можливо спостерігати з рентгенівської дифрактограми кулачка з сталі 45 і наплавленим шаром електродами ОЗШ-3 при Со-Ка випромінювання рис. 3 найбільші інтенсивні лінії відповідають $a-F e(2.02 ; 1,43 ; 1,01)$, також присутні менш інтенсивні лінії $F e_{2} B(3,66 ; 2,75$; $1,73 ; 1,31)$ і $F e B(2,2 ; 1,9 ; 1,56 ; 1,49 ; 1,1)$. Окремо можливо виділити фази карбіду заліза $\mathrm{Fe}_{3} \mathrm{C}(2,38 ; 1,97)$ і $\mathrm{FeCr}(2,14)$. Це підтверджує наявність в поверхневому шарі покриття боридів заліза $\mathrm{Fe}_{2} \mathrm{~B}$ і $\mathrm{FeB}$, що є однією з передумов для зміцнення поверхні деталі кулачка.

Виміри мікротвердості робочої поверхні кулачка показали наступні результати 6500-7000 МПа на поверхні і 5500-6000МПа на глибині 25 мкм від поверхні [11].

Для випробування зразків на зносостійкість використовували машина тертя СМЦ-2 (рис. 4 а) (питоме навантаження 1,5 МПа; швидкість тертя 0,8 м/с; шлях 1000 м). Для експрес аналізу задавали найбільш жорсткі умови тертя - підвищену швидкість і тиск контактуючих пар в умовах сухого тертя, що в 10-15 раз перевищує умови нормальної експлуатації. Діаграму зносу контрольних зразків із сталі 45 і наплавленим шаром електродами ОЗШ-3 після лазерної обробки наведена на рис. 4 б [12-15].

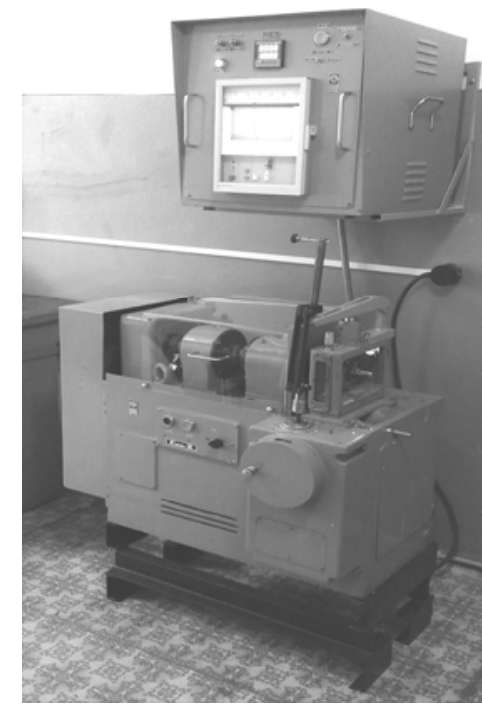

a

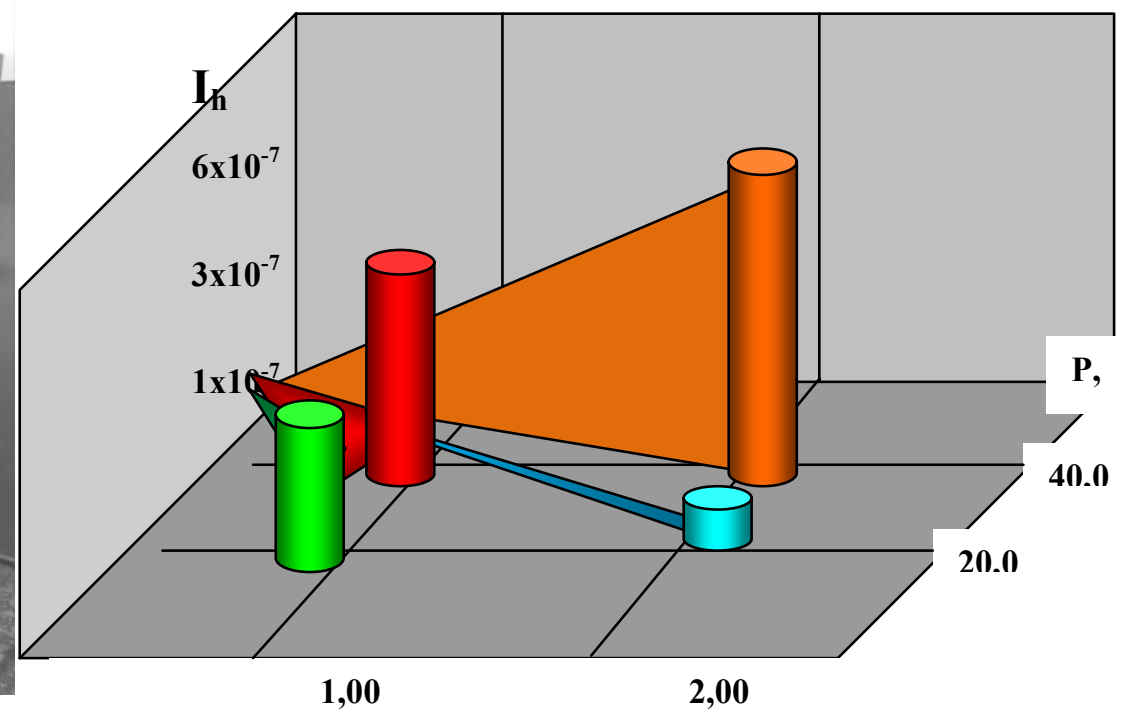

б

Puc. 4. а - машина тертя СМЦ-2 (питоме навантаження 1,5 МПа; швидкість тертя 0,8 м/с; шлях 1000 м. ), б - діаграма зносу контрольних зразків із сталі 45 і наплавленим шаром електродами ОЗШ-3 після лазерної обробки

\section{Висновки}

На підставі аналізу ряду існуючих технологічних способів зміцнення поверхневого шару конструкційних матеріалів досліджено динаміку трансформації їх мікроструктур. Проведені мікроструктурні і рентгенофазові дослідження поверхневого шару сталі 45 з відновленим робочим шаром шляхом наплавлення електродам ОЗШ-3. Проведені виміри мікротвердості зміцнених лазерним боруванням робочих поверхонь. Поверхневі структури, які отримано для сталі 45 3 наплавленим і зміцненим шаром вважаються цікавими, як з точки зору забезпечення прогнозованої міцності поверхневого шару робочої поверхні деталі, так і з точки зору закономірностей формування стійких до зношування мікроструктур. 


\section{Список використаної літератури}

1. S. Dmitriyev, A. Koudrin, A. Labunets, M. Kindrachuk. Functional coatings application for strengthening and restoration of aviation products / AVIATION//Vol IX, № 4 2005. 39-45.

2. Франценюк И.В., ФранценюкЛ.И. Альбом микроструктур чугуна, стали, цветных метал лов и их сплавов. -М.:ИКЦ «Академкнига», 2004. -136с.

3. M. Kindrachuk, A.Shevchenko, A.Kryzhanovskyi. Improvement of the quality of Ti-CO system plasma coating by laser treatment. AVIATION//Vol 20(4), 2016. 155-159.

4. Л.С. Малинов. Диференцированные обработки сплавов для повышения их свойств - перспективное направление в материаловедении. /Новые материалы и технологии в металлургии и машиностроении.// Науковий журнал 2'2012 Запоріжжя, ЗНТУ - 51-56с.

5. J.M. Poate, G. Foti, D.C. Jacobson /Surface modification and alloying by laser, ion, and electron beams/ M. Машиностроение 1987 - c. 301.

6. Hu W.W., Herman H., Clayton C.R. et.aI. In: Ion Implatation Metallurgy / ed. G.M. Preece and J.K. Hirvonen. New York: TSM-AIME, 1980.

7. О.Г. Чернета, Р.Г. Волощук, О.М. Коробочка Дослідження технологічних способів формування зносостійких покриттів на основі лазерної обробки. // Збірник наукових праць «Перспективні технології та прилади»//м. Луцьк листопад 2014 р. - Луцьк: ЛНТУ, Вип. 5(2) - 2014. С. 171-176.

8. ASTM Card File (Diffraction Date Card and Alphabetscal and Grouped Numerical Index of X-Ray Diffraction Date)-Philadelphia; Ed.By ASTM,1969.

9. Горелик С.С. Рентгенограми и электроннооптический анализ / С.С. Горелик, Ю.А. Скаков,

Л.Н. Расторгуев. - М. : МИСИС, 1994. - 328 с.

10. Миркин Л.И. Справочник по рентгеноструктурному анализу поликристаллов / Миркин Л.И. - М. : Физ. - мат. лит, 1961. - 864 с.

11. В.К. Григорович Твердость имикротвердость металлов.-М.: Наука;1976.-С.230.

12. О.Г. Девойно / Технология формирования износостойких поверхностей лазерным легированием / - Минск: УП «Технология», 2001. -180 с.

13. О.Г. Чернета, В.І. Сухомлін, Р.Г. Волощук, Середа Б.П. / Дослідження мікроструктури зношених деталей автомобілів із сталі 45 при відновлені і багатократній термічній обробці. // Перспективні технології та прилади. м. Луцьк / червень 2017 р. - ЛНТУ, - Вип. 10(1) - 2017. C. $212-217$.

14. Б.П. Середа, Н.С. Калініна, І.В. Кругляк / Поверхневе зміцнення матеріалів / Монографія. Запоріжжя: Видавництво Запорізької державної інженерної академії, 2004. - 230 с.

15. О.Г. Чернета, В.І. Сухомлин, О.М. Коробочка Дослідження мікроструктури зношених деталей автомобілів із сталі 45 при відновлені і багатократній термічній обробці. // Перспективні технології та прилади. м. Луцьк червень 2017 р. - ЛНТУ, - Вип. 10(1) - 2017. С. 212-217.

\section{INVESTIGATION OF THE RESTORED SURFACE LAYER OF STEEL-DETAILED ELEMENTS 45 WITH STABILIZING PROCESSING ON SENSITIVITY Cherneta O.G., Suhomlyn V.I., Ralinichenko S.V.}

\footnotetext{
Abstract

Modern methods of strengthening the reproduced working surfaces of parts are considered in the work, technological regimes of surfacing, processing and strengthening of surface layers are selected. Microstructures, X-ray diffraction analysis, tribological examinations and hardened layers of steel 45 with a layer of electrodes OZS-3 of car parts have been carried out. the questions of formation of layered zones in the surface layers of the restorative part, features of structural structure and properties of the working surface after laser treatment with a batting pad are considered. Conducted a cycle of measurements of microhardness of the working layers of the strengthened layer.
} 
The use of combined technologies allows consistently form the layered structure of structures in a material with given properties using doped elements and implementation phases. Laser processing contributes to the grinding of the granules of the main structure of the material. In the surface layer, as a result of re-hardening of the formed structures, new structures and phases arise. Carbides, nitrides, borides, oxides in some cases, as a result of laser treatment, characterized by rapid heating and cooling processes, create new structures and complex forms of formation such as carbonitrides, oxycarbonitrides, borocarbides, etc., which is an indispensable component in the presence of various steels of alloyed elements and also independently enter into processes of formation of structures and phases.

To strengthen the surface layer of the part, a high-power pulse laser GOOS-1 with an accumulation energy of $40 \mathrm{kG}$, a distance to the target of $290 \mathrm{~mm}$, a laser beam diameter of $9 \mathrm{~mm}$, was used. The pre-laser treatment zone was covered with a spin-coating (glutinous mixture of powder boron fractions of 0.3-0.5 and supermonolite (TU U-2406-30440956-003-02). Laser treatment was carried out with the overlap of the corresponding treatment zones due to the transfer of the laser beam by surface, moving and rotating the body of the cam around the axis of rotation.

Leaky structural formations are the result of temperature fluctuations when cooled in the air and are classified as upper bainite. The ferrite-cementite structure in the layer is observed along the boundaries of the grains in the form of plates of ferrite. The sizes of grains and rijki range from 10-20 microns.

The ferrite-carbide structure is observed in the base metal of steel 45 - colony of grains of dark and light color with the sizes, respectively, 8-15 microns and 5-10 microns. Photographs of samples are detected in the deepest layer of aggregate of grains of lamellar perlite and cementite. Under the surface layer (25 microns from the surface) there are separate white boron inclusions, which are the result of laser boring. The sizes of these individual particles do not exceed 5 microns.

\section{References}

[1] Dmitriyev S., Kudrin A., Labunets A., Kindrachuk M. "Functional coatings application for the strengthening and restoration of aviation products" AVIATION. Vol. IX, No. 4 2005. pp. 39-45.

[2] Frantsenyuk I.V., Frantsenyuk I.I. Album of microstructures of cast iron, steel, non-ferrous metals and their alloys. - M .: ICC "Akademkniga", 2004. pp. 123-136.

[3] Kindrachuk M., Shevchenko A., Kryzhanovsky A.. "Improvement of the quality of Ti-CO system by plasma coating by laser treatment". AVIATION. Vol. 20 (4), 2016. pp. 155-159.]

[4] Malinov L.S. "Differentiated processing of alloys to enhance their properties is a promising direction in materials science". New materials and technologies in metallurgy and machine building, Scientific journal 2'2012 Zaporizhzhya, ZNTU - pp. 51-56.

[5] Poate J.M. , Foti G., Jacobson D.C. Surface modification and alloying by laser, ion, and electron beams. M. Mechanical Engineering 1987. pp. 295-301.

[6] Hu W.W., Herman H., Clayton C.R. et.aI. In: Ion Implatation Metallurgy ed. G.M. Preece and J.K. Hirvonen New York: TSM-AIME, 1980. pp. 241-253.

[7] Cherneta O.G., Voloshchuk R.G., Korobochka O.M. "Research of technological methods of formation of wear-resistant coatings on the basis of laser treatment". Collection of scientific works "Perspective Technologies and Devices" city Lutsk November 2014 - Lutsk: LNTU, Vp. 5 (2) - 2014. pp. 171-176.

[8] ASTM Card File (Diffraction Date Card and Alphabetscal and Grouped Numerical Index of X-Ray Diffraction Date) -Philadelphia; Ed.By ASTM, 1969.

[9] Gorelik S.C. X-ray and electron-optical analysis, S.C. Gorelik, Yu A. Skakov, L.N. Rastorguev - M.: MISIS, 1994. pp. 320-328.

[10] Mirkin L.I. Handbook for X-ray diffraction analysis of polycrystals, M.: Fiz.- mat. Lit, 196. pp. $86-95$.

[11] Grigorievich V.K. Hardness of the hardness of metals. -M .: Science, 1976.pp.210-230.

[12] Devoyo O.G. Technology of forming wear-resistant surfaces by laser doping, Minsk: UP "Tehnologiya", 2001. pp. 82-89. 
[13] Cherneta O.G., Sukhomyn V.I., Voloshchuk R.G., Sereda B.P. "Investigation of the microstructure of worn parts of cars from steel 45 when restored and repeated thermal treatment". Perspective technologies and devices. Lutsk / June 2017 - LNTU, - Vip. 10 (1) 2017. pp. 212-217.

[14] Sereda B.P., Kalinina N.E., Kruglyak I.V. Surface reinforcement materials. Monograph. Zaporozhye: Publishing House of Zaporizhzhya State Engineering Academy, 2004. pp. 23-44.

[15] Cherneta O.G., Sukhomlin V.I., Korobochka O.M. "Research of the microstructure of worn parts of automobiles made of steel 45 when reconditioned and repeated thermal treatment". [Perspective technologies and devices]. Lutsk, June 2017, LNTU, - Vip. 10 (1) - 2017. pp. 222-217. 